Issues in theory and methods of teaching foreign languages.

Проблеми теорії і методики навчання іноземних мов

УДК $378+81 ` 25$

https://doi.org/10.31548/philolog2021.03.122

\title{
ФОРМУВАННЯ ПЕРЕКЛАДАЦЬКОЇ КОМПЕТЕНТНОСТІ СТУДЕНТІВ ЗАКЛАДІВ ВИЩОЇ ОСВІТИ
}

\author{
Л. Ф. СоловйовА, кандидат фрілологічних наук, доцент, \\ Поліський національний університет \\ E-mail: larisasolovyova23@gmail.com \\ https://orcid.org/0000-0001-5574-5251
}

\author{
О. С. ЧАСТНИК, кандидат мистецтвознавства, доцент, \\ Національний юридичний університет імені Ярослава Мудрого \\ E-mail: chastnyk@gmail.com \\ https://orcid.org/0000-0001-5188-5097
}

\author{
І. М. ДУМЧАК, кандидат філологічних наук, доцент, \\ Прикарпатський національний університет імені Василя Стефаника \\ E-mail: dumcira2018@gmail.com \\ https://orcid.org/0000-0002-3491-6960
}

\begin{abstract}
Анотація. Сучасні спеціалісти повинні мати не тільки фрахові вміння та навички, що базуються на спеціальних знаннях, але й високий рівень профресійної кваліфрікації, який передбачає критичне мислення, володіння іноземною мовою та здатність використовувати теоретичні надбання у своїй практичній діяльності. Для забезпечення конкурентоспроможності випускників закладів вищої освіти (3ВО) на ринку праці важливе значення має фрормування у них перекладацької компетентності. Мета статті полягає у дослідженні змісту перекладацької компетентності та порядку ії формування у студентів спеціальностей «Економіка», «Комп'ютерні науки», «Інфрормаційні системи та технології». Проаналізовано зміст категорій «компетентність» та «перекладацька компетентність». Розглянуто інноваційні методи викладання іноземної мови, які використовуються з метою фрормування перекладацької компетенції студентів, типи завдань, які зарекомендували себе як найбільш ефективні в процесі навчання, основні типи перекладацьких трансфрормацій. Наголошено на доцільності використання методу тематичних досліджень для розвитку перекладацької компетентності студентів у процесі вивчення іноземної мови у закладах вищої освіти. Встановлено, що робота над перекладом тексту включає окремі етапи, на кожному з яких у студентів формуються такі вміння $і$ навички: розпізнавання оптимальних одиниць перекладу в перекладному тексті, користування адекватними перекладацькими транссрормаціями, знаходження найбільш вдалих еквівалентів одиницям перекладу рідною мовою, критичне оцінювання виконаного перекладу та коригування його у разі потреби. Наголошено, що після вивчення іноземної мови студенти спеціальностей «Економіка», "Комп'ютерні науки», «Інформаційні системи та технології» повинні знати граматику в тому обсязі, в якому вона забезпечує практичні навички перекладу, спеціальну термінологічну лексику, мати словниковий запас у межах предметно-орієнтованої програми, вміти передати зміст прочитаного матеріалу іноземною мовою; вести усне та письмове спілкування, ділову бесіду, написати резюме, організувати ділові переговори, написати наукову статтю тощо. Подальші наукові розвідки у цьому напрямку вбачаються у дослідженні чинників формування профресійної комунікативної компетентності майбутніх перекладачів у процесі фрахової підготовки.
\end{abstract}

Ключові слова: перекладацька компетентність, іноземна мова, методи викладання, переклад, перекладацькі трансформації.

Актуальність дослідження. Світові глобалізаційні процеси формують потребу у спеціалістах, які володіють не тільки фаховими вміннями та навичками, що базуються на спеціальних знаннях, але й високим рівнем професійної кваліфікації, що передбачає критичне мислення, знання іноземної мови та здатність використовувати теоретичні надбання у своїй практичній діяльності.

Сучасне навчальне середовище повинно бути спрямоване на розвиток особистих інтелектуальних здібностей студентів, навичок критичного мислення, комунікативних, перекладацьких навичок, необхідних для розуміння культурного різноманіття, співпраці з представниками різних іноземних бізнескомпаній.

У контексті підвищених вимог з боку суспільства до випускників, які здобули освіту за спеціальностями «Економіка», «Комп'ютерні науки», «Інформаційні системи та технології» важливе значення має формування у них перекладацької компетентності у закладах вищої освіти. На практиці перекладацька компетентність проявляється, передусім, в умінні ведення ділового спілкування іноземною

(ㄱ Л. Ф. Соловйова, О. С. Частник, І. М. Думчак

«International journal of philology» | «Міжнародний філологічний часопис» Vol. 12, № 3, 2021 
Issues in theory and methods of teaching foreign languages.

Проблеми теорії і методики навчання іноземних мов

мовою, висловлення і відстоювання власної позиції у бізнес-переговорах. Розвиток перекладацької компетентності забезпечує конкурентоспроможність випускників 3ВО.

\section{Аналіз досліджень і публікацій.} Проблеми формування перекладацької компетентності студентів у ЗВО досліджували вітчизняні та зарубіжні вчені: І. Аргатюк, $€$. Базилевич, Т. Бойченко, 3. Львовська, М. Степанова, В. Лук'янова, С. Хоцкіна та інші. У своїх наукових працях науковці розглядали: методи викладання іноземних мов [1], методику формування перекладацької компетентності студентів немовних 3ВО [2], сучасні проблеми в перекладі [4], фрормування перекладацької компетенції у студентівекономістів [5,6,9], ділову англійську мову [7], вплив ділової англійської мови на формування професійної компетентності студентів [8], формування наукової компетентності з англійської мови у студентів [10], використання інформаційнокомунікаційних технологій та сучасних методів у навчанні іноземної мови [11], комунікативну компетентність [12]. Незважаючи на численні наукові напрацювання, проблема формування перекладацької компетентності у студентів 3ВО є актуальною і вимагає подальшого вивчення.

Мета статті полягає у дослідженні змісту перекладацької компетентності та порядку її формування у студентів спеціальностей «Економіка», «Комп'ютерні науки», «Інформаційні системи та технології».

Результати. Підбір висококваліфікованого персоналу, здатного забезпечити виживання компанії на ринку, є першочерговим завданням будь-якої компанії. Сучасний фрахівець повинен вільно володіти розмовною та професійною іноземною мовою і активно використовувати її як у повсяқденному житті, так і в своїй сорері діяльності.

Під компетентністю розуміють відповідність вимогам, критеріям та стандартам у різних сфрерах професійної діяльності, здатність отримувати очікувані результати і володіти ситуацією [6, с. 4]. Перекладацька компетентність $€$ частиною загальної компетентності та визначає здатність фахівця спілкуватися, читати та писати іноземною мовою у сфері професійного та ділового спілкування [3, с. 11].

Гнучка модульна структура професійного вивчення іноземної мови та значний обсяг матеріалів дозволяють викладачам вибирати та комбінувати навчальні матеріали. Кожен навчальний підрозділ охоплює розвиток мовних навичок та аудіювання, письма, читання, говоріння, перекладу, ознайомлення із сучасною професійно-діловою термінологією та інформацією [8, с. 68]. Разом з тим, цілі формування перекладацької компетенції фахівців у галузі економіки, комп'ютерних наук та інформаційних технологій відрізняються від цілей, які ставляться при підготовці професійних перекладачів [5, с. 40].

На рис. 1 наведено інноваційні методи викладання іноземної мови, які використовують ЗВО 3 метою фрормування перекладацької компетенції студентів, оскільки традиційні методи недостатньою мірою розвивають їх перекладацькі навички.

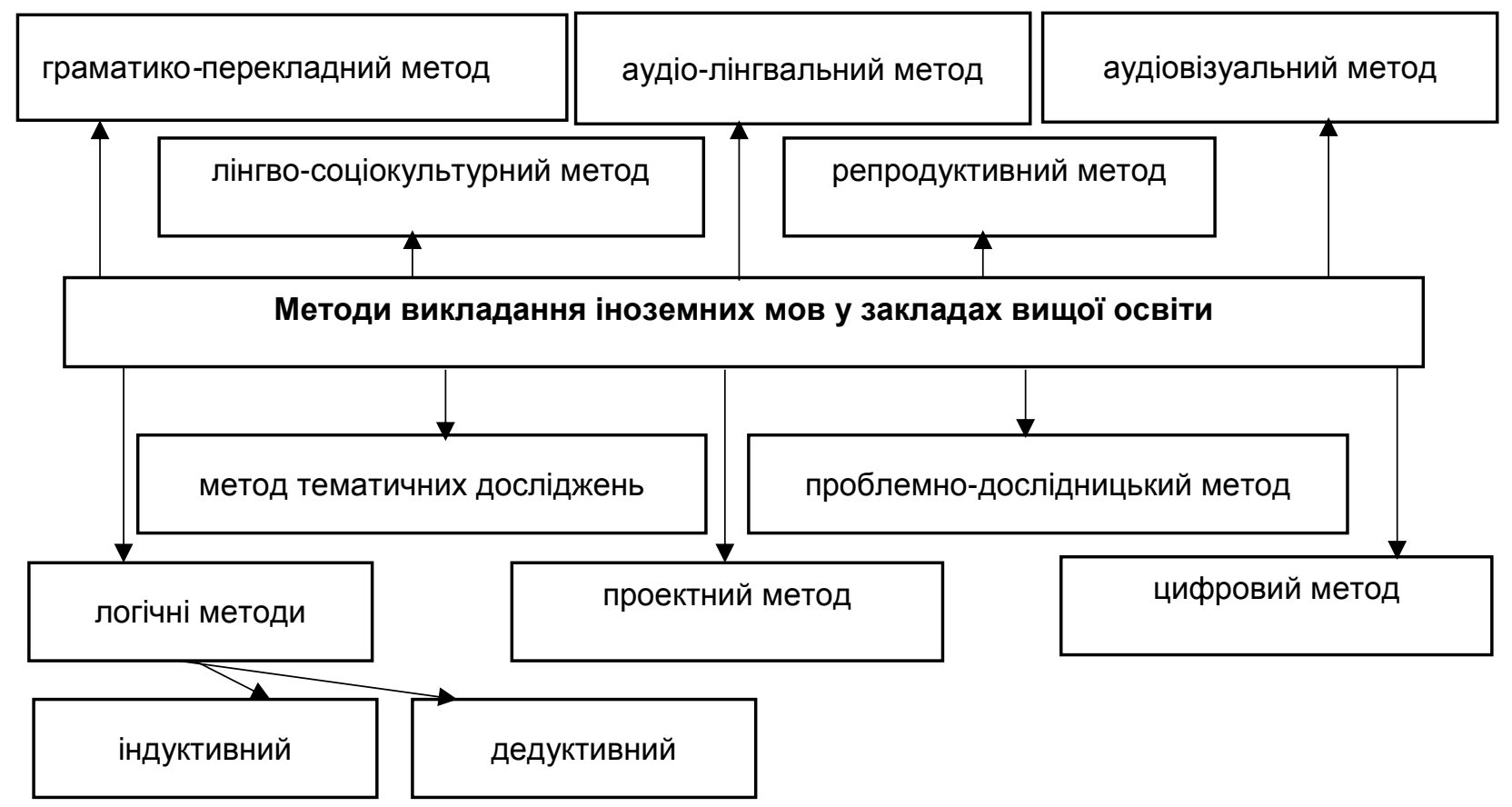

Рис. 1. Методи викладання іноземних мов у 3 ВО $[13$, с. $773 ; 1$, с. 23-24, 11, с. 178]

(C) Л. Ф. Соловйова, О. С. Частник, І. М. Думчак

«International journal of philology» | «Міжнародний філологічний часопис» Vol. 12, № 3, 2021 
Закріпленню набутих знань та мовних навичок якнайповніше сприяє тематичне дослідження, яке трактується як аналіз практичних ситуацій, що передбачає спосіб розгляду, аналіз проблеми, пошук рішень та оцінку на основі певних критеріїв. У процесі тематичного дослідження студенти обговорюють реальні ділові ситуації у штучно створеному профресійному середовищі, що породжує жваву дискусію. Отримані уроки студенти зможуть застосовувати у своїй профресійній діяльності [12, с. 77-78].

Тематичне дослідження дозволяє студентам подивитись на проблему з різних точок зору, навіть якщо вони не мають нічого спільного 3 їх спеціалізацією. Тематичні дослідження використовуються для розвитку перекладацьких компетенцій студентів у межах вивчення іноземної мови. Викладачі, які організують тематичні дослідження, можуть адаптувати ситуації до конкретних потреб студентів [7, с. 42].

Для досягнення еквівалентності та адекватності перекладу перекладач користується спеціальними прийомами перекладацькими трансформаціями, до яких належать: заміни загального типу; заміни значення речення; заміни одного речення двома і більше, а також об'єднання двох i більше речень в одне; конкретизація; генералізація [4, с. 183].

Після ознайомлення студентів 3 основами теорії перекладу розробляють практичний блок формування перекладацької компетенції. Безпосередня робота над перекладом тексту включає чотири основні етапи:

1. Переклад заголовка тексту (отримання поняття про тип і тематику тексту).

2. Швидкий перегляд тексту без фріксації уваги на складних лексичних та граматичних елементах (визначення жанру тексту, його стилістики за наявними словами-маркерами: професійними, науковими термінами, абревіатурами, назвами тощо).

3. Детальний переклад тексту з метою глибокого розуміння написаного (найбільш трудомісткий етап):

- виконання підрядкового перекладу 3 фіксацією уваги для розуміння складних граматичних конструкцій і лексичних одиниць;

- виявлення одиниць перекладу;

- підбір найбільш адекватних еквівалентів для кожної одиниці перекладу оригінального тексту, використання перекладацьких трансформацій з урахуванням вимог перекладу інфрормації якомога ближче до оригіналу без викривлення змісту і забезпечення грамотного звучання тексту на мові перекладу.

4. Повторний перегляд i редагування отриманого перекладу (пошук і виправлення можливих помилок у перекладі, знаходження більш точного, вдалого еквівалента, усунення стилістичних помилок) [2, с. 13-14].

На кожному етапі роботи над перекладом тексту у студентів формуються такі вміння і навички: розпізнавання оптимальних одиниць перекладу в перекладному тексті, використання адекватних перекладацьких трансорормацій, знаходження найбільш вдалих еквівалентів одиницям перекладу на рідній мові, критичне оцінювання виконаного перекладу та коригування його при необхідності.

Для успішного формування перекладацької компетенції доцільно використовувати типи завдань, які зарекомендували себе як найбільш ефективні в процесі навчання:

- завдання на визначення типу, тематики і жанру тексту, що перекладається;

- завдання, спрямовані на формування вміння виявляти оптимальні одиниці перекладу в невеликому тексті іноземною мовою;

- завдання, спрямовані на формування навичок використання перекладацьких трансформацій, а саме - пошук найбільш адекватної перекладацької трансформації (лексичної або граматичної заміни, додавання, опущення, перестановки тощо), для розкриття змісту конкретної одиниці перекладу на рідній мові;

- завдання, спрямовані на фрормування вміння аналізувати і критично оцінювати виконаний переклад тексту з перекладної мови на іншу мову [2, с. 13-14].

Контроль $€$ логічним завершенням кожного з етапів формування перекладацької компетенції. Етап контролю передбачає виконання спеціально розроблених завдань, які дають можливість викладачу скласти уявлення про рівень засвоєння студентами теоретичних знань, а також про рівень сформованості їх практичних умінь і навичок [2, c. 11].

Після вивчення іноземної мови студенти спеціальностей «Економіка», «Комп'ютерні науки», «Інформаційні системи та технології» повинні знати:

- граматику в тому обсязі, в якому вона забезпечує практичні навички перекладу, фрормує навички усного та письмового спілкування;

- спеціальну термінологічну лексику, яка надаватиме можливість майбутньому спеціалісту отримувати та передавати наукову інформацію із своєї спеціальності;

- мати словниковий запас у межах предметно-орієнтованої програми.

Після успішного вивчення курсу «Іноземна мова» студент повинен вміти передати зміст прочитаного матеріалу іноземною мовою; вести усне (діалогічне, монологічне) та письмове спілкування, ділову

(C) Л. Ф. Соловйова, О. С. Частник, І. М. Думчак

«International journal of philology» | «Міжнародний філологічний часопис» Vol. 12, № 3, 2021 
Issues in theory and methods of teaching foreign languages.

Проблеми теорії і методики навчання іноземних мов

бесіду; написати резюме; організувати ділові переговори; написати наукові статті 3 подальшою участю у науково-практичних конфреренціях [10, с. 89].
На рис. 2 відображено результат сорормованої перекладацької компетентності студентів після вивчення іноземної мови.

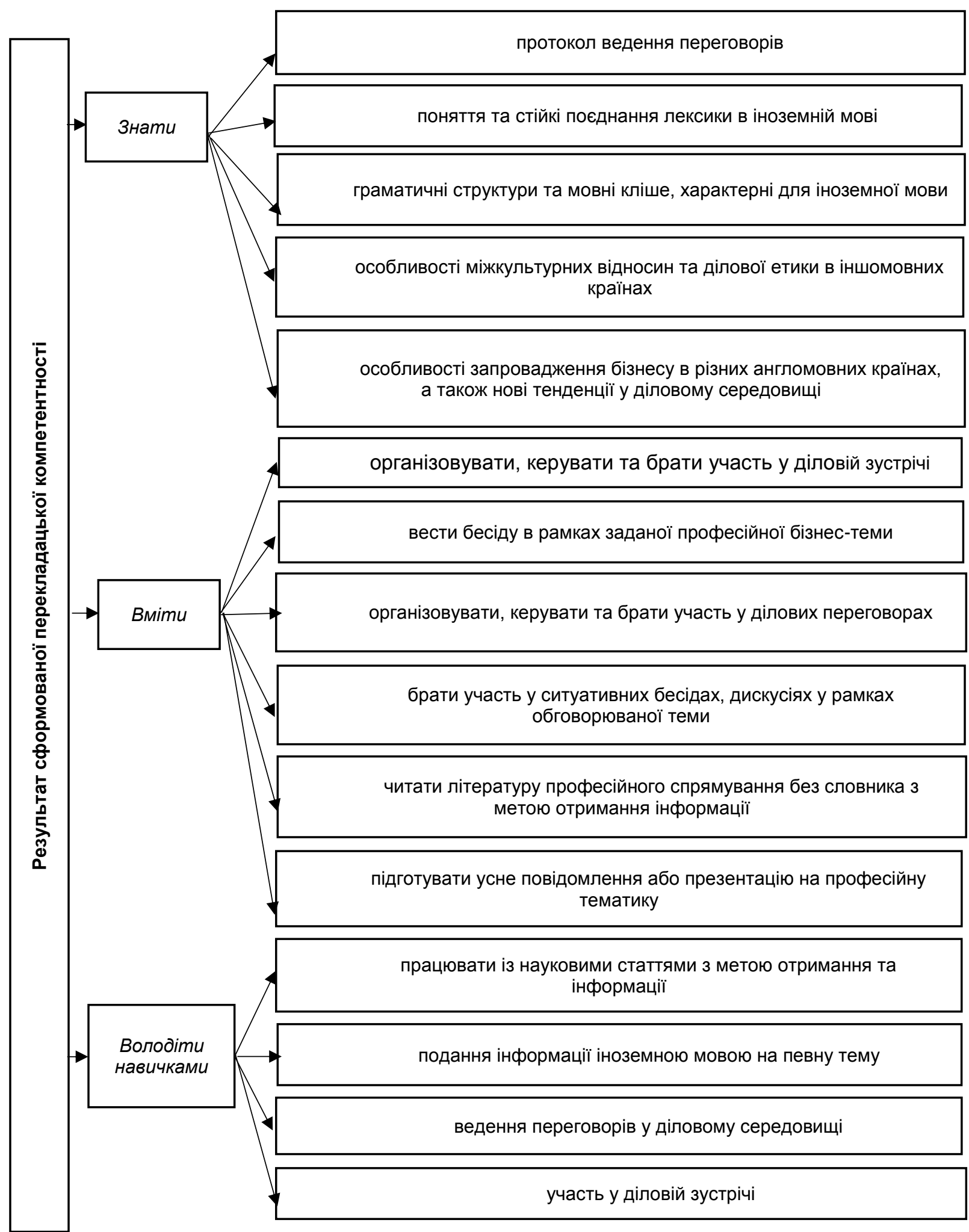

Рис. 2. Результат формування перекладацької компетентності студентів після вивчення іноземної мови [9, с. 38-39]

(C) Л. Ф. Соловйова, О. С. Частник, І. М. Думчак

«International journal of philology» | «Міжнародний філологічний часопис» Vol. 12, № 3, 2021 
Issues in theory and methods of teaching foreign languages.

Проблеми теорії і методики навчання іноземних мов

Проведене дослідження дало можливість узагальнити рекомендації щодо формування перекладацької компетенції студентів:

1) роботу над фрормуванням перекладацької компетенції доцільно починати із вивчення основ теорії перекладу: поняття про одиниці перекладу та перекладацькі трансформації;

2) необхідно сорормувати у студентів навички пошуку оптимальних одиниць перекладу в тексті і застосування найбільш адекватних перекладацьких трансфрормацій для кожної одиниці перекладу;

3) безпосередню роботу, пов'язану із перекладом тексту, необхідно розбивати на етапи;

4) після виконання студентами перекладу текстів рекомендується проводити рефлексію отриманих результатів, зокрема зачитувати найбільш еквівалентні переклади, фіксуючи увагу на вдало використаних перекладацьких трансформаціях, а також аналізувати невдалі переклади, працювати разом зі студентами над виправленням помилок [2, с. 11].

Отже, формування

перекладацької

\section{Список використаних джерел}

1. Аргатюк И. В., Базилевич Е. В. Современные методы преподавания иностранных языков. Мир языков: ракурс и перспективы: сборник материалов IX Международной науч.-практ. Конференции, 26 апреля 2018 г. Минск, Ч. 4. Минск: БГУ, 2018. C. 22-26.

2. Бойченко Т. А. Методика формирования переводческой компетенции студентов неязыковых вузов. Теория и практика научных исследований: психология, педагогика, экономика и управление. 2020. №. 1 (9). С. 7-17.

3. Комплекс нормативних документів для розроблення складових системи галузевих стандартів вищої освіти. Міністерство освіти і науки України, Інститут інноваційних технологій і змісту освіти. Київ, 2008. 69 с.

4. Львовская 3. Современные проблемы перевода. М.: Издательство ЛКИ, 2016. 224 с.

5. Степанова М. М., Лукьянова В. С. Формирование переводческой компетенции у студентов-экономистов при обучении иностранному языку. Вестник Тамбовского университета. Серия: Гуманитарные науки. 2021. Вып. 26. № 191. С. 38-48.

6. Хоцкіна С. М. Формування комунікативної компетентності майбутніх економістів у процесі вивчення гуманітарних дисциплін: автореф. дис. на здобуття наук. ступеня канд. пед. наук: 13.00.04. Київ, 2013. 20 с.

7. Frendo E.. How to Teach Business English. Pearson Educational Limited, England. 2005, $162 \mathrm{p}$.

8. Hà Thị Kim Hằng Influence of business english on formation of professional competence of компетентності студентів фракультетів економіки, комп'ютерних наук та інформаційних технологій сприяє успішному працевлаштуванню випускників і фаховій відповідності вимогам вітчизняного та міжнародного ринків праці.

Висновки. Формування перекладацької компетентності студентів у ЗВО сконцентроване на отриманні якісно нового результату, який відповідав би стану та тенденціям світового освітнього простору. Результатом формування перекладацької компетентності студентів після вивчення іноземної мови $€$ набуття студентами певних вмінь і навичок, зокрема вміння працювати з професійним текстом іноземною мовою, самостійно здобувати нові знання, розвивати особистий творчий потенціал тощо. Подальші наукові розвідки у цьому напрямку вбачаються у дослідженні чинників формування профресійної комунікативної компетентності майбутніх перекладачів у процесі фрахової підготовки.

students. The European Journal of Humanities and Social Sciences, Philology and linguistics, 2020, № 1, pp. 68-70.

9. Kalugina O. A. Development of students' professional communicative competence in an economic higher school. XLinguae Journal, 2016, Vol. 9, No 4, pp. 37-45.

10. Matkarimova G. O.. Formation of the English scientific competence in students of nonfactual faculties. Вопросы науки и образования. 2019, No. 32 (82). C. 88-90.

11. Muratova G., Abraimova N. The use of information-communication technologies and modern methods in teaching a foreign language. Mental Enlightenment Scientific-Methodological Journal, Vol. 2020, No. 2, pp. 175-181.

12. Vasbiev D. G. A Lean Approach as a Means of Achieving Communicative Competence. XLinguae Journal, 2014, Vol. 7, No 4, pp. 75-82.

13. Yuldashova U., Bozorova M., Mansurova N., Ahmedova Z. et al. Language teaching methods: theory and practice. Journal of Critical Reviews, 2020, No 7 (5), pp. 768-775.

\section{References}

1. Argatyuk, I. V., Bazilevich, E. V. (2018). Sovremennye metody prepodavaniya inostrannyh yazykov [Modern methods of teaching foreign languages]. Mir yazykov: rakurs i perspektivy: sbornik materialov IX Mezhdunarodnoj nauch.prakt. Konferencii, 26 aprelya $2018 \mathrm{~g}$. Minsk, Ch. 4. Minsk: BGU, pp. 22-26 [in Russian].

2. Bojchenko, T. A. (2020). Metodika formirovaniya perevodcheskoj kompetencii studentov neyazykovyh vuzov [Methods of formation of translation competence of students of non-language

(С) Л. Ф. Соловйова, О. С. Частник, І. М. Думчак

«International journal of philology» | «Міжнародний філологічний часопис» Vol. 12, № 3, 2021 
universities]. Teoriya i praktika nauchnyh issledovanij: psihologiya, pedagogika, ekonomika i upravlenie, No 1 (9), pp. 7-17 [in Russian].

3. Kompleks normatyvnykh dokumentiv dlia rozroblennia skladovykh systemy haluzevykh standartiv vyshchoi osvity [A set of normative documents for the development of components of the system of industry standards of higher education] (2008). Ministerstvo osvity i nauky Ukrainy, Instytut innovatsiinykh tekhnolohii i zmistu osvity. Kyiv. 69 p. [in Ukrainian].

4. L'vovskaya, Z. (2018). Sovremennye problemy perevoda [Modern problems of translation]. M.: LKI, 224 p. [in Russian].

5. Stepanova, M. M., Luk'yanova, V. S. (2021). Formirovanie perevodcheskoj kompetencii u studentov-ekonomistov pri obuchenii inostrannomu yazyku [Formation of translation competence in students of economics in teaching a foreign language]. Vestnik Tambovskogo universiteta. Seriya: Gumanitarnye nauki, Vol. 26, No 191, pp. 38-48 [in Russian].

6. Khotskina, S. M. (2013). Formuvannia komunikatyvnoi kompetentnosti maibutnikh ekonomistiv u protsesi vyvchennia humanitarnykh dystsyplin [Formation of communicative competence of future economists in the process of studying humanities]: avtoref. dys. na zdobuttia nauk. stupenia kand. ped. nauk: 13.00.04. Kyiv, 20 p. [in Ukrainian].
7. Frendo, E. (2005). How to Teach Business English. Pearson Educational Limited, England. $162 \mathrm{p}$.

8. Hà Thị Kim Hằng (2020). Influence of business english on formation of professional competence of students. The European Journal of Humanities and Social Sciences, Philology and linguistics, No 1, pp. 68-70.

9. Kalugina, O. A. (2016). Development of students' professional communicative competence in an economic higher school. XLinguae Journal, Vol. 9, No 4, pp. 37-45.

10. Matkarimova, G. O. (2019). Formation of the English scientific competence in students of non-factual faculties. Вопросы науки $u$ образования. № 32 (82). C. 88-90.

11. Muratova, G., Abraimova, N. (2020). The use of information-communication technologies and modern methods in teaching a foreign language. Mental Enlightenment Scientific-Methodological Journal, Vol. 2020, No. 2, pp. 175-181.

12. Vasbiev, D. G. (2014). A Lean Approach as a Means of Achieving Communicative Competence. XLinguae Journal, Vol. 7, No 4, pp. 75-82.

13. Yuldashova,

U., Bozorova, M., Mansurova, N., Ahmedova, Z. et al. (2020). Language teaching methods: theory and practice. Journal of Critical Reviews, No 7 (5), pp. 768-775.

\title{
TRANSLATION COMPETENCE FORMATION OF STUDENTS OF HIGHER EDUCATIONAL INSTITUTIONS
}

\author{
L. F. Soloviova, O. S. Chastnyk, I. M. Dumchak
}

\begin{abstract}
Modern specialists must have not only professional skills and abilities based on special knowledge, but also a high level of professional qualification, which includes critical thinking, knowledge of a foreign language and the ability to use theoretical knowledge in their practice. To ensure the competitiveness of graduates of higher education institutions in the labor market, it is important to form their translation competence. The purpose of the article is to study the content of translation competence and the order of its formation in students majoring in "Economics", "Computer Science", "Information Systems and Technologies". The content of the categories "competence" and "translation competence" is analyzed. Innovative methods of teaching a foreign language used to form students' translation competence, types of tasks that have proven to be the most effective in the learning process, the main types of translation transformations are considered. Emphasis is placed on the expediency of using the method of case studies for the development of students' translation competence in the process of learning a foreign language in higher education institutions. It is established that the work on text translation includes separate stages, at each of which students develop the following skills: recognition of optimal translation units in the translated text, use of adequate translation transformations, finding the most successful equivalents of native language translation units, critical evaluation of translation and adjust it if necessary. It is emphasized that after studying a foreign language, students majoring in "Economics", "Computer Science", "Information Systems and Technologies" must know grammar to the extent that it provides practical translation skills, special terminological vocabulary, have a vocabulary within subject-oriented program, be able to convey the content of the read material in a foreign language; to conduct oral and written communication, business conversation, write a resume, organize business negotiations, write a scientific article, etc. Further scientific research in this direction is seen in the study of the factors of formation of professional communicative competence of future translators in the process of professional training.
\end{abstract}

Keywords: translation competence, foreign language, teaching methods, translation, translation transformations. 